\title{
Analysis of Factors Affecting the Capability of the DPRK Board Members in Financial Supervision (Study on Banda Aceh Local Parliament (DPRK Banda Aceh))
}

\author{
Jalaluddin Juanda* Cut Putri Balqisa \\ Faculty of Economics and Business Universitas Syiah Kuala
}

\begin{abstract}
The purpose of this study is to determine the effect of education level, employment background, education sector, political background and organizational experience on the capability of Banda Aceh local parliament (DPRK Banda Aceh) members in regional financial supervision. This study uses a questionnaire survey to the DPRK Banda Aceh. This study uses a simple random sampling sample selection by taking random samples with different criteria totaling 30 people. This study was analyzed using multiple regression analysis. The results of the study show that the level of education, employment background, education, political background and organizational experience influence the capability of DPRK Banda Aceh members in financial supervision.
\end{abstract}

Keywords: Educational level, Job background, Education sector, Political background, Organizational experience, Regional financial supervision.

DOI: $10.7176 / \mathrm{RJFA} / 10-8-18$

Publication date: April $30^{\text {th }} 2019$

\section{Introduction}

Aceh as a province in Indonesia has brought many changes that directly affect all forms of policies taken by both the government and the laws produced by the local parliament (DPRA) which are regulated in Law No.18 in 2001 concerning regional autonomy which was further confirmed by Law No. 11 of 2006 concerning the governance of Aceh, its status of special autonomy.

In general, Regional Financial Management explains that supervision of regional finances is carried out by the board, as well as an examination of external regional financial management, namely the Financial Investigation Body (BPK). In general, the legislature has three functions, namely:

1. Legislation function (function of making legislation)

2. Budget Function (function of composing a budget)

3. Monitoring function (function to oversee executive performance).

One important aspect in the framework of implementing regional autonomy and decentralization is the financial and city budget problem (APBK). Therefore, it is necessary to have a very large role for Banda Aceh local parliament (DPRK Banda Aceh) members to control the economic finance policy (APBK) which is economical, efficient, effective, transparent and accountable. However, in reality, these demands must also be confronted with the factual condition that most of the DPRK members in this period were dominated by new faces, who were elected and appointed from election winning parties who had different educational and occupational backgrounds before becoming members of the DPRK.

Several years earlier there had been a problem involving the misappropriation of APBK (local budget) carried out by the DPRK Banda Aceh where the leaders and members of the parliament at the budget planning stage had included a number of expenditure items that were not in accordance with regulations and intended to enrich themselves, resulting in losses to regional finances (ICW , Detikcom, 2004).

These problems are interesting and important cases, because they greatly affect the interests of individuals, society, nation and state. The weaknesses that occur in the legislative role in overseeing regional finances may occur due to the weaknesses of the political system or individuals as political actors. One of the functions of the DPRK is the oversight function. In the behaviorism approach, the individual is seen as actually carrying out political activities.

Based on the explanation above, the weak function of the legislative supervision is a factor that influences the legislative performance on the executive. Regional financial supervision conducted by the board is influenced by the system and individuals personally (Sastroatmodjo, 1995). The weaknesses that occur in the legislative role in overseeing regional finances may occur due to the weakness of the political system or individuals as political actors. Actually political activities are carried out by individuals, while the behavior of political institutions is basically guided by the behavior of individuals with certain patterns. Therefore, to explain the behavior of an institution (in this case the DPRK), it is not the institution which needs to be examined, but the background of the individual who actually controls the institution, namely the parliament members.

Based on this case, it can be concluded that fundamental errors may arise from mathematical calculation errors, errors in the application of accounting policies, misinterpretation of facts and fraud or negligence. Public 
accountants should act independently because they are the party in charge of checking and reporting any irregularities in recording financial statements. As competent auditors, they should know whether the audited reports are based on fictitious reports or not, and also the auditor must be able to maximize the period of time that has been given well in carrying out its audit duties.

These phenomena indicate that the audit function has not been effective and that the quality of the auditor is still weak. Therefore, it is important for an auditor of public accountants to maintain competence, independence, and not to spend a long time in carrying out their duties.

\section{Educational level, employee background, education sector, political background, organizational experience, and capability in financial supervision}

According to Siegel and Helene (1989) the behavior of people who occupy certain organizational positions is to unite groups within the organization. The role of DPRK members, especially in the supervision of regional finances (APBK), is aimed at ensuring whether the implementation of city budget is in accordance with the rules and objectives that have been determined in an effective and efficient manner. Therefore, Murni and Witono (2003) found that education levels have a significant effect on the role of DPRK members in supervising regional finance and are very important, because regional financial supervision is expected to realize a transparent, accountable, and effective government. Based on the results of these findings, the hypothesis is proposed as follows:

H1 The level of education, occupational background, education, political background, and organizational experience have an influence on the Regional Financial Supervisors in DPRK in Banda Aceh.

The level of education in this study is the formal education in the form of a standard education starting from elementary to tertiary level and non-formal education.

This is supported by Kartikasairi (2012) who argued that the level of education has a positive and insignificant effect on the role of DPRD members in regional financial supervision. The level of education has an influence on the role and performance of the DPRD in supervising regional finances (Wiyana, 2011: 121). This shows that the higher the level of education of DPDR members, the better the role of DPRD members is in overseeing regional finance.

H2 The level of education influences the Regional Financial Supervision of the DPRK Banda Aceh.

\subsection{Relationship between Job Background and Regional Financial Supervision}

Personal background is a self background that is attached to an individual. In this study, the Personal Background is reflected in the level of education and the relevance of the job background. Personal Background is closely related to human resources. Personal Background includes job background (Winarna and Murni, 2007). Kartikasari (2012) found that the job background had a positive and insignificant effect on the role of DPRD members in the supervision of regional finances. Sari (2010) explained that the job background affected the performance of the DPRD in the supervision of regional finance (APBD). Based on the results of these findings, the hypothesis is formulated as follows:

H3 The job background affects the regional financial supervision of the DPRK Banda Aceh.

\subsection{Relationship between education and Regional Financial Supervision}

Knowledge is gained from education and experience. Knowledge will contribute better if supported by adequate education and experience in financial supervision. This is supported by Indriantoro and Supomo (1999) who argued that knowledge is gained from education and experience.

Wibowo (2012) explained that there is a difference in the variance in the education sector towards the role of the parliament in regional financial supervision. This shows that differences in the education level affect the role of parliament in regional financial supervision. Kartikasari (2012) also found that education has a positive and insignificant effect on the role of DPRD members in overseeing regional finance. Based on the results of these findings, the proposed hypothesis is formulated as follows:

H4 The education level influences regional financial supervision of the DPRK Banda Aceh.

\subsection{Relationships between Political Background and Regional Financial Supervision}

Political background is a factor suspected of influencing the supervisory function. The level of education and adequate experience in politics and government have an influence on the role and performance of the DPRD in overseeing regional finance, because experience will determine the maturity level of DPRD members in politics (Wiyana 2011: 121).

This is supported by the research of Putri et al. (2016). Political background has a positive effect on the oversight function of budget implementation. Rosita (2016) found that the political background had a positive effect on Regional Financial Supervision with regression coefficient value of Political background variable of 0.840 . Wiyana (2011: 121) explains that the level of education has an influence on the role and performance of DPRD in regional financial supervision. Sari (2010) found that political background influenced the performance 
of DPRD in the supervision of regional finance/APBD. Based on the results of these findings, the proposed hypothesis is formulated as follows:

H5 Political background has an effect on influencing regional financial oversight of the DPRK Banda Aceh.

\subsection{Relationship between Organizational Experience and Regional Financial Supervision}

In organizing, each individual can interact both directly and indirectly with all related structures in order to interact well and effectively. This is supported by Sari (2010) who explained that organizational experience influences the performance of the DPRD in the supervision of regional finance/APBD. Kartikasari (2012) found that Organizational Experience has a positive and significant influence on the role of DPRD members in overseeing regional finances. Based on the results of these findings, the proposed hypothesis is formulated as follows:

H6: Organizational experience influences the regional financial supervision of the DPRK Banda Aceh The following research models are used:

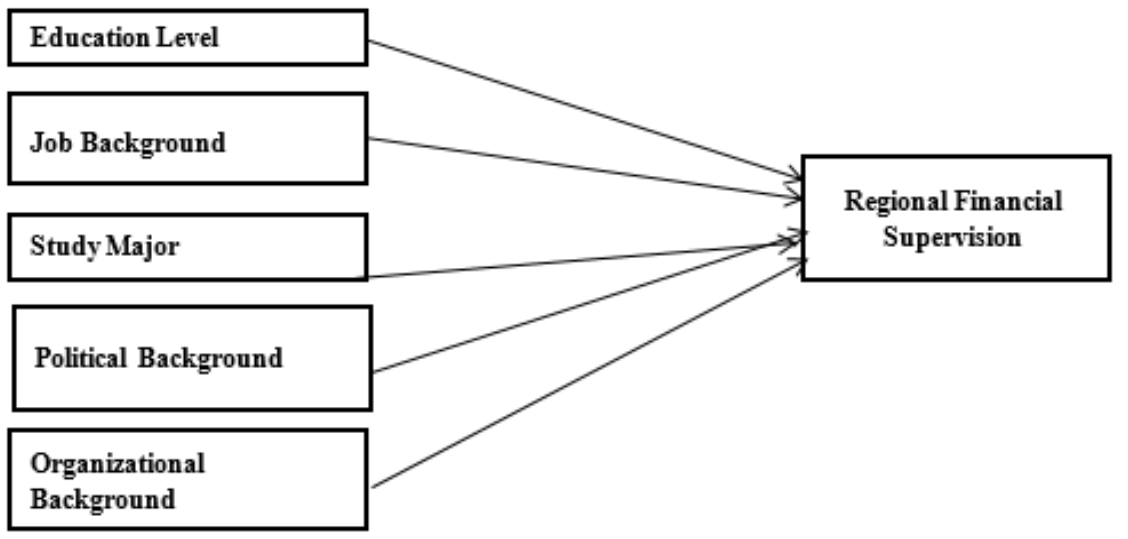

Figure 1. Research Framework

\section{Research method}

This research is census research, where the research uses all elements of the population into research data. The target population in this study is 30 members of DPRK Banda Aceh. The research subjects who would be made respondents were DPRK members

The characteristics of respondents in are as follows:

Table 1. Respondents Characteristics

\begin{tabular}{|l|c|c|}
\hline Respondents Identity & Amount & \% \\
\hline Gender & 29 & $96.7 \%$ \\
Male & 1 & $3.3 \%$ \\
Female & 3 & $10 \%$ \\
Age & 27 & $90 \%$ \\
36-40 years & 14 & $46.7 \%$ \\
More than 40 years & 16 & $53.3 \%$ \\
Education level & & \\
High school & 21 & $70 \%$ \\
Wochelor's degree & 9 & $30 \%$ \\
\hline One period & & \\
More than one period & &
\end{tabular}

Source: Processed data (2018)

\subsection{Variable Definition and Measurement}

Regional financial supervision $(\mathrm{Y})$ is the use of DPRD rights at all stages of the budget starting from the APBD preparation stage, APBD approval, APBD implementation and APBD accountability. The role of DPRD members in regional financial supervision is measured using a questionnaire developed by Sopanah (2003). The measurement scale used is a five-point Likert scale.

Level of Education (X1) in this research is the last education taken by members of the DPRD, both formal and informal (Sopanah, 2003). The measurement scale used is a five-point Likert scale.

Job Background (X2) is the relationship between the last job or profession of members of the DPRD before elected and the supervisory function. The development of this variable uses a questionnaire designed by Sopanah (2003). The measurement scale used is a five-point Likert scale. 
Education Major (X3) is the link between the department or field of study of the education of DPRD members with the supervision and financial functions. This variable is measured using a questionnaire developed by Sopanah (2003). The measurement scale used is a five-point Likert scale.

Political background (X4) is the history or information of a person in the political world which consists of several dimensions (Winarna and Sari, 2007). The measurement scale used is a five-point Likert scale.

Organizational Experience (X5) is the experience of a person as a DPRD member (Sopanah, (2003). The measurement scale used is a dummy scale. Each of these values can be seen in Table 2.

Table 2. Score Interpretation

\begin{tabular}{|c|c|}
\hline Score & Category \\
\hline $1-1.79$ & Strongly disagree \\
\hline $1.80-2.59$ & Disagree \\
\hline $2.60-3.39$ & Slightly disagree \\
\hline $3.40-4.19$ & Agree \\
\hline $4.20-5.00$ & Strongly agree \\
\hline
\end{tabular}

Source: Processed data (2018)

\section{Research Result}

Descriptive statistical results for each variable and respondent's answers can be seen as follows:

\subsection{Level of education}

The responses given by respondents to statements relating to education level are shown in Table 3.

Tabel 3. Respondents Education Level

\begin{tabular}{|c|c|c|c|c|c|c|}
\hline \multirow{2}{*}{ Statements } & \multicolumn{7}{|c|}{ Response Alternatives } & \multirow{2}{*}{ Average } \\
\cline { 2 - 7 } & 1 & 2 & 3 & 4 & 5 & \\
\hline 1 & & & 4 & 6 & 20 & 4.53 \\
\hline 2 & & & 6 & 16 & 8 & 4.06 \\
\hline 3 & & & 4 & 16 & 10 & 4.20 \\
\hline 4 & & & 4 & 17 & 9 & 4.16 \\
\hline Total & & & 18 & 55 & 47 & \multirow{2}{*}{$\mathbf{4 . 2 4}$} \\
\hline Multiplied Score & & \multicolumn{7}{|c|}{$509 / 120=4.24$} & 235 & \\
\hline
\end{tabular}

Source: Processed data (2018)

From Table 3, it can be seen that the education level obtains an average value of 4.24 for all education level statement items.

\subsection{Job Background}

The responses given by respondents to statements relating to job background (X2) are shown in Table 4.

Table 4. Respondents Answer on Job Background

\begin{tabular}{|c|c|c|c|c|c|c|}
\hline \multirow{2}{*}{ Statement } & \multicolumn{5}{|c|}{ Answer } & \multirow{2}{*}{ Average } \\
\cline { 2 - 6 } & 1 & 2 & 3 & 4 & 5 & 4.03 \\
\hline 1 & & & 1 & 27 & 2 & 4.06 \\
\hline 2 & & & & 28 & 2 & 4.06 \\
\hline 3 & & & 1 & 26 & 3 & 4.00 \\
\hline 4 & & 1 & & 27 & 2 & 4.00 \\
\hline 5 & & 1 & 1 & 25 & 3 & 4.10 \\
\hline 6 & & & & 27 & 3 & 4.07 \\
\hline 7 & & & 1 & 26 & 3 & \multirow{2}{*}{$\mathbf{4 . 1 0}$} \\
\hline Total & & 2 & 3 & 133 & 23 & \\
\hline Total (Average Score) & & 4 & 9 & 532 & 115 & \\
\hline
\end{tabular}

Source: Processed data (2018)

From Table 4 it can be seen that for all items the statement of occupational background obtains an average value of 4.10 for all items of employment background statement with the last professional indicator.

\subsection{Study Major}

To see the responses given by respondents to statements relating to the study major variables (X3) are shown in Table 5 . 
Table 5. Respondents' Answers on Education

\begin{tabular}{|c|c|c|c|c|c|c|}
\hline \multirow{2}{*}{ Statements } & \multicolumn{5}{|c|}{ Answers } & \multirow{2}{*}{ Average } \\
\hline & 1 & 2 & 3 & 4 & 5 & \\
\hline 1 & 2 & & 1 & 21 & 6 & 3.97 \\
\hline 2 & 2 & & & 20 & 8 & 4.06 \\
\hline 3 & 2 & & & 22 & 6 & 4.00 \\
\hline 4 & 2 & & 1 & 22 & 5 & 3.93 \\
\hline Total & 8 & & 2 & 85 & 30 & \multirow{3}{*}{4.03} \\
\hline Multiplied by & 8 & & 6 & 340 & 150 & \\
\hline Total (Average Score) & \multicolumn{5}{|c|}{$504 / 125=4.03$} & \\
\hline
\end{tabular}

\section{Source: Data processed (2018)}

From Table 5, it can be seen that for all items in education, the average score is 4.03 with indicators of majors or fields of study of DPRD members.

\subsection{Political Background}

The responses given by respondents to statements relating to political background variables (X4) are shown in Table 6.

Table 6. Respondents' Answers on Political Background

\begin{tabular}{|c|c|c|c|c|c|c|}
\hline \multirow{2}{*}{ Statements } & \multicolumn{5}{|c|}{ Answers } & \multirow{2}{*}{ Average } \\
\cline { 2 - 7 } & 1 & 2 & 3 & 4 & 5 & 4.00 \\
\hline 1 & & & 1 & 28 & 1 & 4.06 \\
\hline 2 & & & & 28 & 2 & 4.03 \\
\hline 3 & & & 1 & 27 & 2 & 4.10 \\
\hline 4 & & & & 27 & 3 & 4.06 \\
\hline 5 & & & & 28 & 2 & 4.06 \\
\hline 7 & & & 1 & 26 & 3 & 4.03 \\
\hline Total & & 1 & & 26 & 3 & 4.03 \\
\hline Multiplied by & & 1 & 3 & 190 & 16 & \\
\hline Total (Average Score) & & 2 & 9 & 760 & 80 & \\
\hline
\end{tabular}

Source: Data processed (2018)

From Table 6 it can be seen that all items of political background statement obtain an average score of 4.05 with indicators of political experience, experience in DPRD, political party background, ideological background of political parties and origin of parliamentary commission.

\subsection{Organizational Experience}

The fifth variable (X5) is organizational experience. Organizational experience variables use dummy variables. Seventy per cent of respondents has experience of one period at parliament, and $30 \%$ of respondents has experience of more than one period at parliament.

\subsection{Regional Financial Supervision}

Responses given by respondents on statements relating to variables of regional financial supervision (Y) are shown in Table 7. 
Table 7. Respondents' Answers to Regional Financial Supervision

\begin{tabular}{|c|c|c|c|c|c|c|}
\hline \multirow{2}{*}{ Statements } & \multicolumn{7}{|c|}{ Answers } & \multirow{2}{*}{ Average } \\
\cline { 2 - 6 } & 1 & 2 & 3 & 4 & 5 & 4.00 \\
\hline 1 & & & 6 & 18 & 6 & 3.97 \\
\hline 2 & & & 7 & 17 & 6 & 4.03 \\
\hline 3 & & & 6 & 17 & 7 & 4.00 \\
\hline 4 & & & 7 & 16 & 7 & 4.06 \\
\hline 5 & & & 6 & 16 & 8 & 4.06 \\
\hline 6 & & & 6 & 16 & 8 & 4.00 \\
\hline 7 & & & 7 & 16 & 7 & 4.03 \\
\hline 9 & & & 2 & 25 & 3 & 4.26 \\
\hline 10 & & & 2 & 18 & 10 & 3.93 \\
\hline Amount & 1 & & 2 & 24 & 3 & \multirow{2}{*}{$\mathbf{4 . 0 4}$} \\
\hline Multiplied by & 1 & 0 & 51 & 183 & 65 & 325 \\
\hline
\end{tabular}

Source: Data processed (2018)

\subsection{Instrument Testing Results}

The quality of data obtained from the use of researcher instruments can be evaluated through validity and reliability tests (reliability tests) based on the Cronbach Alpha coefficient. Both of these tests were carried out statistically with the help of SPSS.

\subsection{Validity Test Results}

Validity test results show that the data used are valid as shown in Table 8.

Table 8 . Validity Test Results

\begin{tabular}{|c|c|c|c|c|}
\hline Variables & Statements & $R$ count & $\mathbf{R}$ table & Remarks \\
\hline \multirow[t]{4}{*}{ Education Level $\left(\mathrm{X}_{1}\right)$} & TP1 & 0.866 & 0.300 & Valid \\
\hline & TP2 & 0.864 & 0.300 & Valid \\
\hline & TP3 & 0.902 & 0.300 & Valid \\
\hline & TP4 & 0.925 & 0.300 & Valid \\
\hline \multirow[t]{7}{*}{ Job Background $\left(\mathrm{X}_{2}\right)$} & $\mathrm{P} 1$ & 0.681 & 0.300 & Valid \\
\hline & $\mathrm{P} 2$ & 0.768 & 0.300 & Valid \\
\hline & P3 & 0.863 & 0.300 & Valid \\
\hline & $\mathrm{P} 4$ & 0.605 & 0.300 & Valid \\
\hline & P5 & 0.753 & 0.300 & Valid \\
\hline & P6 & 0.958 & 0.300 & Valid \\
\hline & P7 & 0.863 & 0.300 & Valid \\
\hline \multirow[t]{4}{*}{ Study Major $\left(\mathrm{X}_{3}\right)$} & BP1 & 0.940 & 0.300 & Valid \\
\hline & $\mathrm{BP} 2$ & 0.976 & 0.300 & Valid \\
\hline & BP3 & 0.970 & 0.300 & Valid \\
\hline & BP4 & 0.972 & 0.300 & Valid \\
\hline \multirow[t]{7}{*}{ Political Background (X4) } & POL1 & 0.653 & 0.300 & Valid \\
\hline & POL2 & 0.846 & 0.300 & Valid \\
\hline & POL3 & 0.812 & 0.300 & Valid \\
\hline & POL4 & 0.931 & 0.300 & Valid \\
\hline & POL5 & 0.771 & 0.300 & Valid \\
\hline & POL6 & 0.849 & 0.300 & Valid \\
\hline & POL7 & 0.763 & 0.300 & Valid \\
\hline Organizational Experience $\left(\mathrm{X}_{5}\right)$ & \multicolumn{4}{|c|}{ No validity test because there is only one question } \\
\hline
\end{tabular}




\begin{tabular}{|l|c|c|c|c|}
\hline \multicolumn{1}{|c|}{ Variables } & Statements & R count & R table & Remarks \\
\hline $\begin{array}{l}\text { Regional Financial Supervision } \\
\text { Y) }\end{array}$ & PKD1 & 0.943 & 0.300 & Valid \\
\cline { 2 - 5 } & PKD2 & 0.847 & 0.300 & Valid \\
\cline { 2 - 5 } & PKD3 & 0.986 & 0.300 & Valid \\
\cline { 2 - 5 } & PKD4 & 0.960 & 0.300 & Valid \\
\cline { 2 - 5 } & PKD5 & 0.959 & 0.300 & Valid \\
\cline { 2 - 5 } & PKD6 & 0.959 & 0.300 & Valid \\
\cline { 2 - 5 } & PKD7 & 0.960 & 0.300 & Valid \\
\cline { 2 - 5 } & PKD8 & 0.684 & 0.300 & Valid \\
\cline { 2 - 5 } & PKD9 & 0.750 & 0.300 & Valid \\
\cline { 2 - 5 } & PKD10 & 0.682 & 0.300 & Valid \\
\hline
\end{tabular}

Source: Data processed (2018)

Based on the results of data processing in Table 8, it can be explained that the variables of education level, occupational background, study major, political background, and regional financial supervision obtain a calculated value greater than 0.300 . This shows that all variables are declared valid and the next process can be carried out.

\subsection{Reliability Test Results}

Reliability test results are shown in Table 9

Table 9. Reliability Test Results

\begin{tabular}{|c|l|c|c|c|}
\hline No & \multicolumn{1}{|c|}{ Variables } & Item Amount & CronbachAlpha & Validity \\
\hline 1 & Education Level $\left(\mathrm{X}_{1}\right)$ & 4 & 0.910 & Good \\
\hline 2 & Job Background $\left(\mathrm{X}_{2}\right)$ & 7 & 0.874 & Good \\
\hline 3 & Study major $\left(\mathrm{X}_{3}\right)$ & 4 & 0.975 & Good \\
\hline 4 & Political Background $\left(\mathrm{X}_{4}\right)$ & 7 & 0.894 & Good \\
\hline 5 & Organizational Experience $\left(\mathrm{X}_{4}\right)$ & 1 & $\begin{array}{c}\text { No validity test because there is only } \\
\text { one question }\end{array}$ \\
\hline 6 & Regional Financial Supervision $(\mathrm{Y})$ & 10 & 0.966 & Good \\
\hline
\end{tabular}

Source: Data processed (2018)

Based on Table 9, it can be explained that the level of education, job background, study major, political background and regional financial supervision gained the value of alpha greater than 0.800 . Thus the measurement of reliability on all research variables shows that reliability measurement meets the credibility of Cronbach Alpha.

\subsection{Hypothesis Testing Results}

After testing the validity and reliability, the next step is to evaluate and interpret using multiple linear regression analysis. The results of regression testing using the SPSS program can be seen in Table 10.

Table 10. Coefficients

\begin{tabular}{|c|c|c|c|c|c|}
\hline \multirow{2}{*}{ Model } & \multicolumn{2}{|c|}{$\begin{array}{c}\text { Unstandardized } \\
\text { Coefficients }\end{array}$} & Standardized Coefficients & \multirow{2}{*}{ S } & \multirow{2}{*}{} \\
\cline { 2 - 5 } & B & Std. Error & Beta & & \\
\hline 1 Constant & -2.370 & 0.758 & & -3.127 & 0.005 \\
\hline Education Level & 0.745 & 0.070 & 0.795 & 10.591 & 0.000 \\
\hline Job Background & 0.117 & 0.183 & 0.059 & 0.640 & 0.528 \\
\hline Study Major & 0.450 & 0.050 & 0.705 & 8.929 & 0.000 \\
\hline Political Background & 0.246 & 0.193 & 0.112 & 1.272 & 0.215 \\
\hline Organizational Experience & -0.069 & 0.098 & -0.057 & -0.710 & 0.485 \\
\hline
\end{tabular}

a. Dependent Variable: Regional Financial Supervision

Based on Table 10 can be written multiple linear regression equations as follows:

$\mathrm{Y}=2.370+0.745 \mathrm{X} 1+0.117 \mathrm{X} 2+0.450 \mathrm{X} 3+0.246 \mathrm{X} 4-0.069 \mathrm{X} 5+\mathrm{e}$

Based on the equation, the constant of 2.370 means that if the variables of level of education, job background, study major, political background and organizational experience are considered constant, then the value obtained from the regional financial supervision variable is 2.370 .

\subsection{Simultaneous Test Results}

Simultaneous test is carried out statistically and the results can be shown in Table 4.10. Testing the first hypothesis 
(H1) in this study uses the following conditions:

- H01: $\beta 1=\beta 2=\beta 3=\beta 4=\beta 5=0$; education level, job background, study major, political background and organizational experience simultaneously have no effect on regional financial supervision.

- Ha1: there is at least one $\beta i \neq 0 ;(i=1,2,3)$; education level, job background, study major, political background and organizational experience simultaneously influence regional financial supervision. Based on Table 4.10 it can be seen that the value of all regression coefficients is not equal to zero $(\beta i \neq 0 ; i=1,2,3)$. This means that the null hypothesis ( $\mathrm{H} 0)$ is rejected and Ha is accepted, meaning that the level of education, work background, study major, political background and organizational experience simultaneously influence regional financial supervision.

\subsection{Individual Test Results}

To examine the effect of independent variables partially or individually on the dependent variable, we need to look at the regression coefficient $(\beta)$ of each independent variable, whether it is zero $(0)$ or not. The stages in making a hypothesis one are:

1. Determine the null hypothesis (Ho) and alternative hypothesis (Ha)

The second hypothesis $(\mathrm{H} 2)$

- H02: $\beta 1=0$; the level of education does not affect regional financial supervision.

- Ha2: $\beta 1 \neq 0$, the level of education has an effect on regional financial supervision.

The third hypothesis (H3)

- H03: $\beta 2=0$; the job background does not affect regional financial supervision.

- Ha3: $\beta 2 \neq 0$, the job background has an effect on regional financial supervision.

The fourth hypothesis (H4)

- H04: $\beta 3=0$; the study major has no effect on regional financial supervision.

- Ha4: $\beta 3 \neq 0$, the study major influences regional financial supervision.

The fifth hypothesis (H5)

- H05: $\beta 4=0$; the political background does not affect regional financial supervision.

- Ha5: $\beta 4 \neq 0$, the political background influences regional financial supervision.

Sixth hypothesis (H6)

- H06: $\beta 5=0$; the organizational experience does not affect regional financial supervision.

- Ha6: $\beta 5 \neq 0$, the organizational experience influences regional financial supervision.

a. Results of Testing the Effect of Education Levels on Regional Financial Supervision

The test of the second hypothesis, namely the influence of the level of education on regional financial supervision is carried out by looking at the regression coefficient $(\beta 1)$. Based on Table 4.10 , the regression coefficient $(\beta 1)$ for education level variables $(\mathrm{X} 1)$ is 0.745 , where $\beta 1 \neq 0$. The results of this test accept the alternative hypothesis that the level of education influences regional financial supervision or they reject the null hypothesis (H0). The regression coefficient $(\beta 1)$ of the level of education (X1) is 0.745 . This means that every 1 unit of change in the variable of audit knowledge will increase audit knowledge by 0.745 in interval scale units assuming the variables of job background (X2), study major (X3), political background (X4) and organizational experience (X5) are considered constant.

b. Results of Testing the Effect of Job Background on Regional Financial Supervision

The testing of the third hypothesis, namely the influence of job background on regional financial supervision is carried out by multiple linear regression analysis with the help of SPSS. The test of the effect of job background on regional financial supervision is done by looking at the regression coefficient ( $\beta 2)$. Based on Table 4.10, the regression coefficient $(\beta 2)$ job background is 0.117 , where $\beta 2 \neq 0$. The test results accept alternative hypothesis that the job background influences the regional financial supervision or they reject the null hypothesis (H0). The regression coefficient $(\beta 2)$ of job background $(\mathrm{X} 2)$ is 0.117 . This means that every 1 unit of change in the job background will increase regional financial supervision by 0.117 in interval scale units with assumptions that education level variables (X1), study major (X3), political background (X4) and organizational experience (X5), are considered constant.

c. Results of Testing the Effect of Study Major on Regional Financial Supervision

The testing of the fourth hypothesis, namely the influence of the study major on regional financial supervision is carried out by multiple linear regression analysis with the help of SPSS. Based on Table 4.10, the regression coefficient $(\beta 3)$ of the study major (X3) is 0.450 , where $\beta 3 \neq 0$. The test results accept the alternative hypothesis that the study major influences regional financial supervision or they reject the null hypothesis (H0). The regression coefficient ( $\beta 3$ ) of study major (X3) is 0.450 . This means that each unit of change in the variable of study major will increase regional financial supervision by 0.450 in interval scale units with assumptions that education level variables (X1), job background (X2), political background (X4) and organizational experience (X5) are considered constant.

d. Results of Testing the Effect of Political Background on Regional Financial Supervision

Testing the fifth hypothesis, namely the influence of political background on regional financial supervision is 
carried out by multiple linear regression analysis with the help of SPSS. Based on Table 4.10, the regression coefficient $(\beta 4)$ of political background $(\mathrm{X} 4)$ is 0.246 , where $\beta 4 \neq 0$.

The test results accept alternative hypotheses, namely the political background influences the supervision of regional finances or rejects the null hypothesis (H0). Regression coefficient $(\beta 4)$ political background $(\mathrm{X} 4)$ is 0.246 . This means that every 1 unit of change in the political background variable will increase regional financial supervision by 0.246 in interval scale units with assumptions on education level variables (X1), employment background (X2), education (X3) and organizational experience (X5), considered constant.

e. Results of Testing the Effect of Organizational Experience on Regional Financial Supervision

The testing of sixth hypothesis, namely the influence of organizational experience on regional financial supervision is carried out by multiple linear regression analysis with the help of SPSS. Based on Table 4.10, the regression coefficient ( $\beta 5$ ) of organizational experience (X5) is -0.069 , where $\beta 5 \neq 0$. The test results accept the alternative hypothesis that the organizational experience influences the regional financial supervision or they reject the null hypothesis (H0). Regression coefficient $(\beta 5)$ of organizational experience (X5) is -0.069 . This means that each unit of change in the variable of organizational experience will reduce regional financial supervision by -0.069 with assumptions on the variables of education level (X1), job background (X2), study major (X3) and political background (X4) are considered constant.

\section{References}

Indonesian Corruption Watch (2004). Kasus penyelewengan terhadap APBK (Cases of misappropriation of APBK).

Kartikasari, Dewi. (2012). Pengaruh Personal Background, Political Background, Pemahaman Regulasi terhadap Peran anggota DPRD dalam Pengawasan Keuangan Daerah (Studi Kasus pada DPRD Kabupaten Boyolali). (Effect of Personal Background, Political Background, Understanding of Regulations on the Role of DPRD Members in Regional Financial Supervision (Case Study in Boyolali Regency DPRD). AAJ 1(1): 12-19.

Putri, F, S, Basri, H, and Arfan, M. (2016). Pengaruh Personal Background,Political Background dan Pemahaman Anggota DPRA tentang Pengelolaan Keuangan Aceh terhadap Fungsi Pengawasan Pelaksaan Anggaran Legislatif di Pemerintahan Aceh. (Effects of Personal Background, Political Background and Understanding of DPRA Members on Aceh Financial Management against the Function of Supervision of Legislative Budget Implementation in Aceh Government). Jurnal Magister Akuntansi, Post-Graduate Syiah Kuala University: 24-35.

Republic of Indonesia, (2001). Law No.18 of 2001 on Autonomy.

Republic of Indonesia, (2006). Law No. 11 of 2006 on Aceh Government.

Sari, Imelda. (2010). Pengaruh Personalbackground, Political background, dan Pengetahuan Dewan tentang Anggaran Terhadap Kinerja DPRD dalam Pengawasan Keuangan Daerah(APBD). (Effects of the Personal Background, Political background, and Knowledge of the Board on Budget on DPRD Performance in Regional Financial Supervision (APBD)). University of North Sumatra Postgraduate Program Thesis

Sastroatmodjo, Sudijono. (1995). Perilaku Politik. (Political Behaviour). Semarang: IKIP Semarang Press

Siegel, G. and Ramanauskas, H. (1989). Behavioral Accounting. United States of America. South-Western Publishing Co.

Sopanah. (2003). Pengaruh Partisipasi Masyarakat dan Transparansi Kebijakan Publik terhadap Hubungan antara Pengetahuan Dewan tentang Anggaran dengan Pengawasan Keuangan Daerah. (Effects of Public Participation and Transparency of Public Policy on the Relationship between Board Knowledge on Budgets and Regional Financial Supervision). Thesis. Jogjakarta: Gajah Mada University.

Wibowo, S, A. (2012). Pengaruh Personal Background, Political Background dan Pengetahuan Dewan tentang Anggaran terhadap Peran DPRD dalam Pengawasan Keuangan Daerah. (Effect of Personal Background, Political Background and Board Knowledge on Budget on the Role of DPRD in Regional Financial Supervision) Jurnal Akuntansi dan Investasi, Vol. 13 No. 1: 44-52.

Winarna, J and Murni, S. (2007). Pengaruh Personal Background, Political Background dan Pengetahuan Dewan tentang Anggaran terhadap Peran DPRD dalam Pengawasan Keuangan Daerah (Studi Kasus di Karesidenan Surakarta dan Daerah Istimewa Yogyakarta Tahun 2006). (Effect of Personal Background, Political Background and Board Knowledge on Budget on the Role of DPRD in Regional Financial Supervision (Case Study in the Residency of Surakarta and Special Region of Yogyakarta in 2006)). Proceedings of SNA X. Surakarta: Sebelas Maret University.

Wiyana, Anim. (2011). Pengaruh Personalbackground dan Political culture terhadap hubungan antara pengetahuan dewan tentang anggaran dengan pengawasan keuangan daerah. (The influence of personal background and political culture on the relationship between board knowledge about the budget and regional financial supervision). Article, Makassar: STIEM Bongaya 